高分子論文集 (Kobunshi Ronbunshu), Vol. 52, No. 5, pp. 272-280 (May, 1995)

\title{
ナイロン6/ポリアミドエラストマーアロイの高次構造と モルフォロジー*
}

\author{
詹 茂盛*1・栗山 卓*1・成澤 郁夫*1・藤本 元弘*2
}

（受付 1994 年 11 月 7 日・審查終了1 995 年 1 月 5 日）

\begin{abstract}
旨 ナイロン 6/熱可塑性エラストマーアロイの構造をDSC, レオグラフ, X 線回折装置, 偏光顥微鏡, 光散 乱装置, 画像解析装置, および走査型顥徽鏡を用いて調べた. 用いた熱可塑性エラストマーはタイマー酸ポリアミ ドェラストマーであり，ハードセグメントがナイロンオリゴマー, ソフトセクメントがポリエーテルからなるもの である.これらのアロイの槽造は相溶化浏を添加したときとも比较検討した. DSC および力学損失の曲線からこれ らポリマー間の部分的な相溶性を指摘した. ナイロン 6 の不均一な球晶構造がアロイ化により均一な球晶構造に変 わる. また, アロイに相溶化刜を添加することでより微細な球晶構造が得られることも明らかになった。
\end{abstract}

1 はじめに

ポリマーアロイでは主として耐衙撃性の向上がその開 発の主な目的となっている。そそのなかであエンジニアリ ングプラスチックとして, 1980 年代からナイロン系をマ トリクスとする耐衝擊性アロイの研究が注目されてお り, 例えば，Wu党はナイロン 66 (PA66)/反応性コム (PR rubber) アロイの耐衛撃強度が PA66 のそれより 60 倍向上できたと報告している. その他に, PA6/ethylenepropylene-dicyclopentadiene grafted with maleic anhydride (EPDM) $)^{2}, \mathrm{PA6} /$ ポリフェニレンエーテル $(\mathrm{PPE})^{3)}$, PA6/スチレンーアクリロニトリルコポリマー (SAN)4), PA6/プロピレン(PP) ylstyrene) (BrXP-50) ${ }^{6}, \mathrm{PA6} /$ チレンープロピレンゴム (EPR) ${ }^{7)}$, PA6/ブタジェンコム (BR) $\left.{ }^{8}\right)$, PA6/styrene-ethylene-butene-styrene (SEBS)9), PA6/コアーシェルゴム (コア:フチルーアクリルコム, シェル:PMMA) (EXL 3300), およびPA6/コアーシェルコム (コア：ブタジェン コム, シェル: PMMA) (EXL3607) ${ }^{10)}$ など枚挙のいとま のないぐらいの各種のナイロン系アロイが相次いで発表 されている.これらの結果を総括してみると, エラスト マーの混合でアロイの耐衝撃強さは向上するものの, 単 純なエラストマーのみの混合ではその程度はあまり大き くなく，2 例だけが母材の 20 倍になっているのみであ $3^{6)}$ ）．これに対して第 3 相あるいは相溶化㓮の存在が

*本報を「ナイロン6/ポリアミドエラストマーアロイの高次 構造とその物性 第 1 報」とする.

*1 山形大学工学部（-992 米沢市城南 4-3-16)

*2富士化成工業(株)技術研究所（354 埼玉県入間郡三芳町 竹間沢 253-2)
あると,アロイの街撃強さはナイロン母材の 28 倍以上 に向上できることが報告されている(10).すなわち，エラ ストマーを添加した熱可塑性ポリマーアロイに共通する ことであるが，結晶性ナイロン系ポリマーアロイの場合 であその耐街撃性の向上の程度は, 分散しているエラス トマーの種類や分散状態, 界面の強さの違いで大きく異 なってくる゙1)

さらに，ナイロン系アロイのような結晶性高分子のア ロイに限れば，マトリックスにエラストマーを添加する 効果としては, (i) 結晶構造を微細化させる, (ii) 結晶う メラあるいは球晶間に変形しやすい構造を増加させる, (iii) 分散粒子による応力集中により結晶ラメラの変形を 促進することなどの機構が考えられる．特にナイロン 6 のような結晶系アロイの強靱性はエラストマーの分散モ ルフオロジーに依存するとともにアロイにおける結晶構 造そのものにも関連することが考えられる。

本研究の目的は, 従来の 2 重結合を有するゴムの代わ りに熱可塑性エラストマーを用いてアロイを構成するこ とである. この理由は, 通常のゴムと比较して, アロイ を製造するときの押出機での加工性や，また加硫工程を 必要としないためアロイのスクラップの再利用も可能で あり、リサイクルなどの点においてその取り扱いが有利 となることが予想されるからである。しかも，マトリッ クスと近似した分子構造を一部に有するエラストマーを 選択できることもマトリックスとの親和性を考えれば有 利である. 本研究では熱可塑性エラストマーとしてナイ ロンをマトリックスとすることでポリアミド系エラスト マーを選んだ.

一般に熱可塑性ポリアミド系エラストマーはハードセ グメントとしてナイロンオリゴマー，綱目鎖に相当する 
ソフトセグメントとしてポリエーテルから構成されてい る. ハードセグメントのナイロンオリゴマーの末端は反 応性に富むアミノ基を持つので, マトリックスのナイロ ンでは官能基同士との反応により界面が安定する可能性 がある. また, 软質のソフトセグメントは強度的には弱 い相であるポリエーテル部分が変形によりボイドあるい はキャビテーションが形成されやすい.

\section{2 実鋻方法}

\section{1 試料}

本研究で用いたマトリックスは東レ(株)の結晶性ナイ ロン 6 (CM1017) である. 基礎的な物性之は, 数均分子 量が 25000 , 密度が $1.14,20^{\circ} \mathrm{C}$ RH65\% 平衡時の吸水率 が $4.2 \%$, 粘度が $1277 \mathrm{P} / 250^{\circ} \mathrm{C}$, 融点が $225^{\circ} \mathrm{C}$, ガラス転 移温度が $50^{\circ} \mathrm{C}$ である. 混合したエラストマーは富士化 成工業(株)のダイマ-酸系重合脂肪酸ポリアミドエラス トマーTPAE-10C, TPAE-10, およびTPAEE-8G であ る. その特徽はハードセグメントとして二つの種類の直 鎖ポリアミドのセグメント 1 とセグメント 2 からなり， TPAE-10C, TPAE-10 は八ードセグメントとソフトセグ メントの割合を同じにしてハードセグメントの割合を変 えたものであり, TPAEE-8G はンフトセグメントの量 を增加したものである. 3 種類エラストマーの数均分子 量はほぼ同じで 21000 で，融点はそれぞれ 170.5, 161.5, $151.5^{\circ} \mathrm{C}$ で，ガラス転移温度はいずれも約 $-50^{\circ} \mathrm{C}$ であ る.

相溶化肪には日本油脂(株)のモデイパー $\mathbf{A}$ シリース 相溶化剤エチレンーエチルアクリレート一無水マレイン酸 共重合体とポリメチルメタクリレートとのグラフトコポ リマー (A 8200) および日本住友化学(株)のボンドフ アースト (BONDFAST)E グレードのエチレンーグリシ ジルメタクリレートコポリマー(BFE)を用いた.これ らの相溶化剂はマレイン酸基とエポキシ基を含有するた め高い反応性と低いガラス転移温度 $\left(T_{3}<-25^{\circ} \mathrm{C}\right)$ を 持っている. 混合比はエラストマーの含有量 5〜20\%wt で, 相溶化剤の含有量が $5 \%$ wt とした.

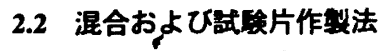

試料はフフレンドおよびホットプレス成形前に真空乾燥 器中で $60^{\circ} \mathrm{C}$ で 1 週間以上減圧乾燥を行った。混合は笠 松化工研究所製の直径 $35 \mathrm{~mm}$ のニータールーターを用

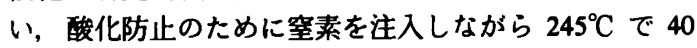
$\mathrm{rpm}, 50 \mathrm{~min}$ 間混練して, 回転数 $150 \mathrm{rpm}$ で押し出して ペレットとした. このペレットをホットプレスにより $250^{\circ} \mathrm{C}, 150 \mathrm{~kg} / \mathrm{cm}^{2}$ で加圧して成形板を得た。 また少量 試料の混合では東洋精機(株)製ブラベンターと新興セル ビック(株)製手動射出成形機を用いて試験片を作製し た.このときは混練温度を $245^{\circ} \mathrm{C}$, 回転数を $80 \mathrm{rpm}$, 添 加量を $50 \mathrm{~g}$, 混練時間を $5 \mathrm{~min}$ として, 酸化防止のため
に窒素を注入しながら混練した，また手動射出成形機の 射出温度は $245^{\circ} \mathrm{C}$, 金型温度は $70^{\circ} \mathrm{C} と し て, 60 \times 10 \times 1$ $\mathrm{mm}$ の大きさの試験片を得た。

\section{3 测定法}

以下の各種測定を行った。

（1）レオロジー：混練における反応性を調べるため に東洋精機(株)製のラボプラストミル R-60型ブラベン ターを用い, $245^{\circ} \mathrm{C}, 80 \mathrm{rev} / \mathrm{min}$, せん断速率比 $=182.4$ / $121.6\left(\mathrm{~S}^{-1} / \mathrm{S}^{-1}\right), 5 \mathrm{~min}$ でトルクを測定した.

（2）DSC 測定：マック・サイエンス(株)製熱分析シ ステムの DSC-3100 型とセイコー電子工業(株)製熱分析 システムの DSC-220 型装置を用い，試料 $3.0 \sim 5.0 \mathrm{mg}$ を 精密秤量後 $10^{\circ} \mathrm{C} / \mathrm{min}$ の昇温速度で $30^{\circ} \mathrm{C}$ 加ら $270^{\circ} \mathrm{C}$ に

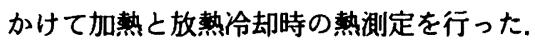

（3）動的粘弾性測定：東洋精機(株)製の動的粘弾性 測定装置を用い，試験片の幅を $10 \mathrm{~mm}$ 、スパン間を 10 $15 \mathrm{~mm}$, 厚さを $80 \sim 100 \mu \mathrm{m}$ とし, および周波数を 10 $\mathrm{Hz}$ ，昇温速度を $2^{\circ} \mathrm{C} / \mathrm{min}$ として測定した.

(4) 偏光顕微鏡と光散乱による結晶構造の観察:

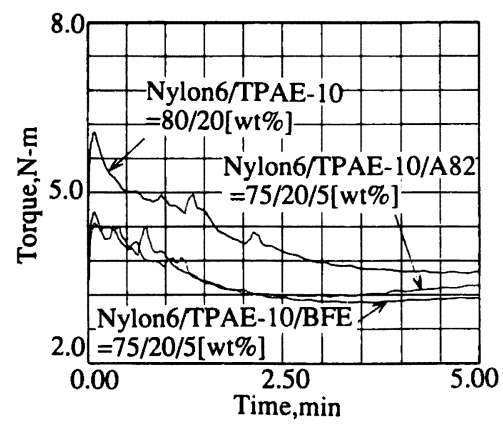

Fig. 1. Brabender torque response with time for Nylon 6/TPAE-10 alloys.

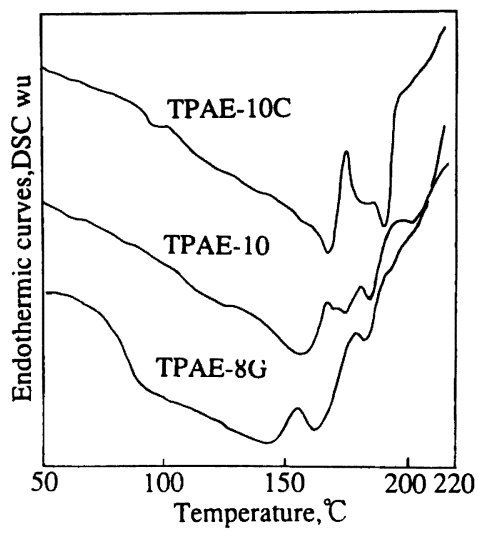

Fig. 2. Endothermic curves of polyamide elastomers. 
㩻・栗山・成澤・藤本
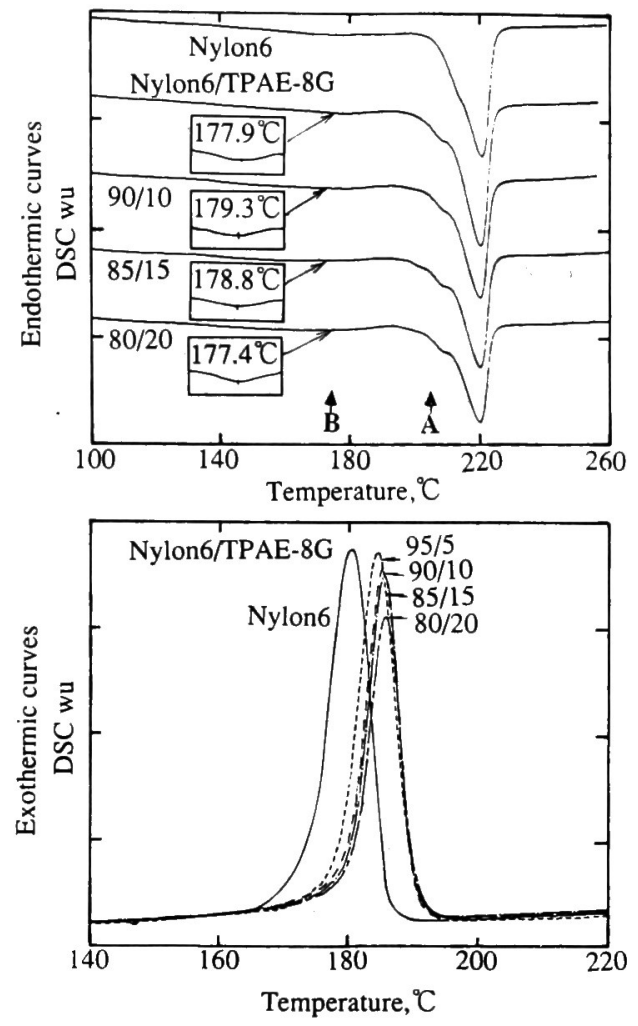

Fig. 3. Endothermic and exothermic curves for Nylon 6/TPAE-8G alloy.

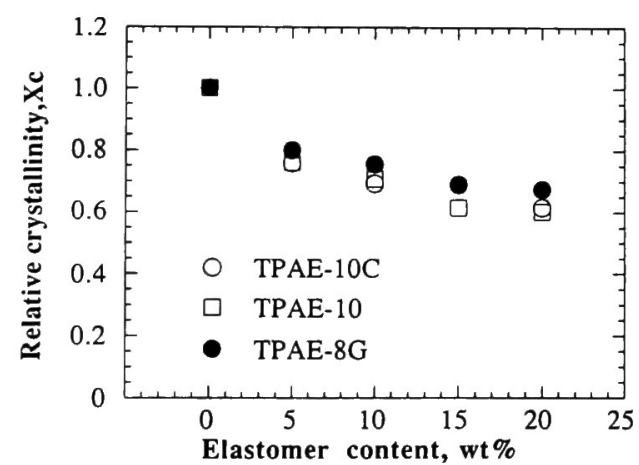

Fig. 4. Change in relative crystallinity with elastomer content.

ホットプレスの成形片をミクロトームにより薄く切り出 し, 偏光顕微鏡を用い結晶構造の観察を行った。またエ ラストマー含有量の增加に対しての球晶の平均的寸法の 変化を調べるために日本光学(株)製光散乱装置を用い, 高温真空乾燥機を用いて等温結晶化による試験片の光散 乱写真を撮影した。

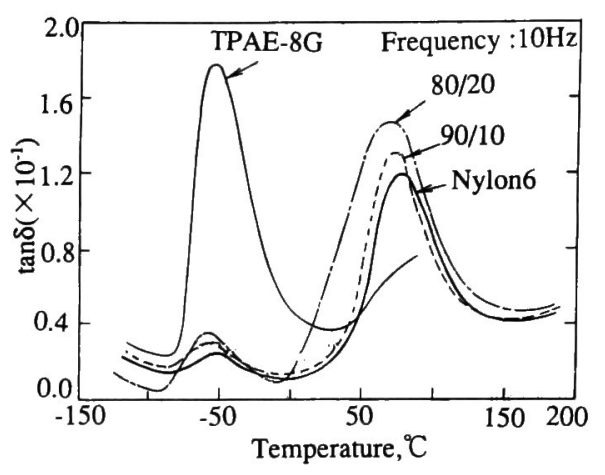

Fig. 5. Mechanical loss tangent against temperature for Nylon 6/TPAE-8G alloy.

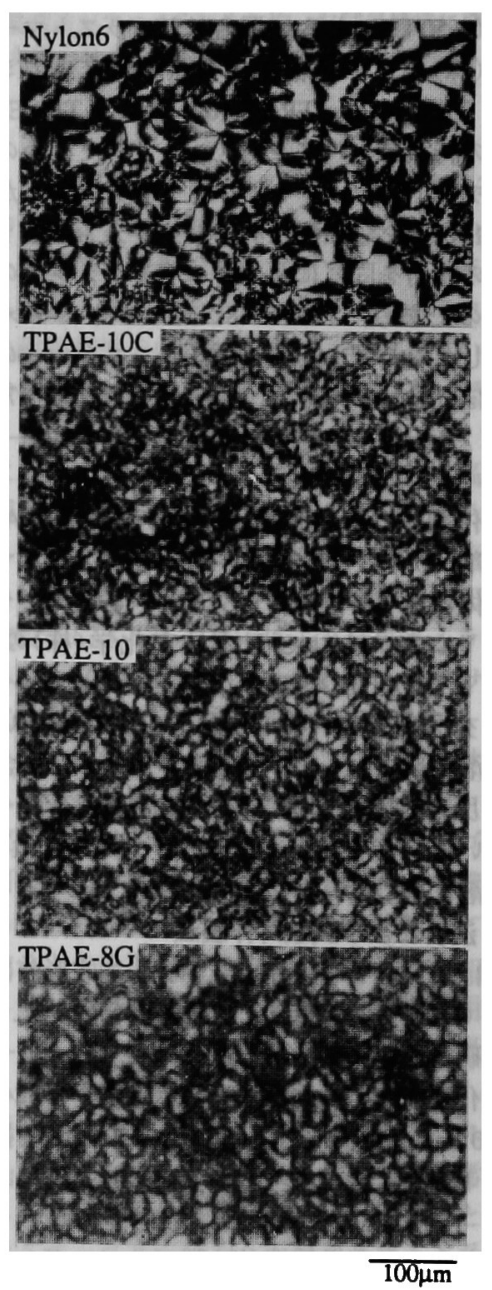

Fig. 6. POM photos of crystalline structure of Nylon 6 and Elastomers. 
ナイロン 6/ポリアミドエラストマーアロイの高次構造とモルフォロジー
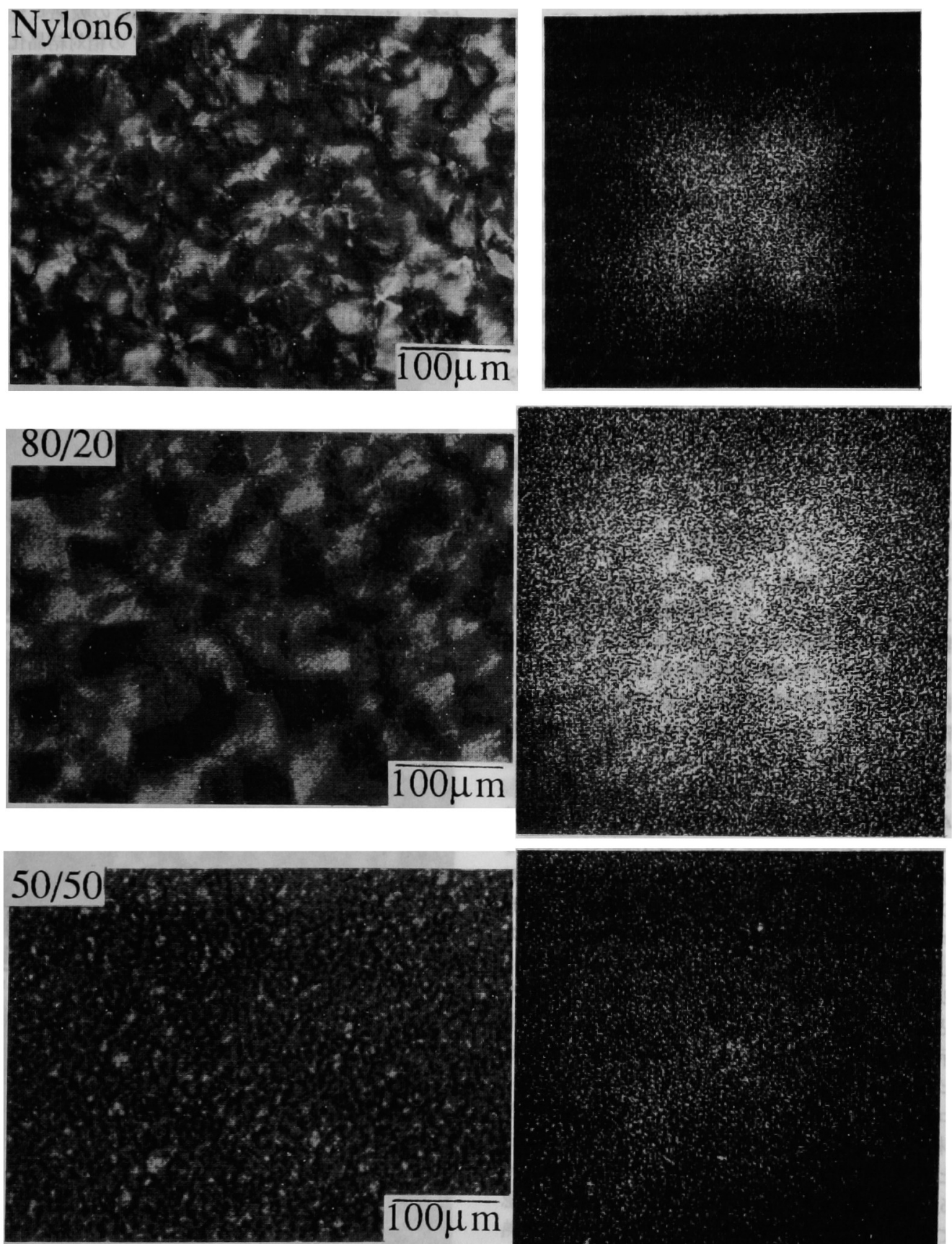

(a) POM Photos

(b) $H_{v}$ light scattering patterns

Fig. 7. POM photos and $H_{v}$ light scattering patterns for Nylon 6 and Nylon 6/TPAE-10 alloys. 
(5) X 線回折による結晶構造分析：RAD- A (Rigaku Rotaflex) $X$ 線装置を用い, $2 \theta=8^{\circ} \sim 30^{\circ}$ の範囲でフイル 厶 $\left(10 \times 10 \times 1 \mathrm{~mm}^{3}\right)$ で測定した. 测定条件は Cu-Ka, 50 $\mathrm{kV}, 200 \mathrm{~mA}, \mathrm{Ni}$ フイルター, 走查速度 $2 \mathrm{deg} / \mathrm{min}$ であっ た.

(6) SEM による形態観察と画像解析：試験片を液体 窒素 $\left(-160^{\circ} \mathrm{C}\right)$ 中に $10 \mathrm{~min}$ 以上浸し冷却した後に衝撃 切断して, その後ブチルアルーコール中に 50〜96時間 浸漬しエラストマー粒子を溶解・㔀離させた. さらにデ シヶータ内で 1 週間以上真空乾燥させた後, 金蒸着し て, 日立 S-450 型走查電子顕微鏡 (SEM) を用い, 8000 倍率で観察・写真撮影を行った，また，日本アビオニク ス (株) 製 EXCEL-II 型 TVイメージプロセットTVIP4100 (II) 画像装置によりその写真の画像分析を行った.

(7) 相分離構造の観察: 試料を $\mathrm{RuO}_{4}$ により染色し, 低真空反射電子顕微鏡 (LSEM) により相分離構造を観 察した.

\section{3 䊅果と考察}

\section{1 トルクおよび粘度}

Fig. 1 にそれぞれナイロン6/TPAE-10=80/20, およ び相溶化剂をナイロン 6/TPAE-10/A8200, BFE=75/ 20/5 割合で加えたときの混練時のトルク変動を示した. この結果より $5 \mathrm{~min}$ 間の混練範囲内での混練終期に, 相 溶化剂を加えた場合にはトルクの上昇が見られ，混練中 に反応の進行することがわかる.

\subsection{DSC}

TPAE-10C, 10, 8G エラストマー，およびこれらのブ レンド物の吸熱・放熱過程をDSCにより調べた. Fig. 2 はエラストマー単独, Fig. 3 はナイロン6/TAPE-8G ア ロイの DSC 曲線を示す. Fig. 2 から 3 種類のエラスト マーが 170〜220 C の範囲内でそれぞれ約 3 個のピーク を有していることを示している. Fig. 3 のナイロン 6/ TPAE-8G アロイではエラストマーの含有量が 5, 10, 15, 20\% とその増加につれてわずかではあるが, 図中の矢印 A で示すショルダーがナイロン 6 の吸熱ピークである 最大ピークに接近する.このことはナイロン 6/TPAE-8 Gアロイにある程度の部分的な相溶性が存在すること を意味する. また図には示さないがナイロン 6/TAPE10C とナイロン6/TAPE-10についても吸熱挙動はナイ ロン 6/TAPE-8G アロイでほとんど差がない結果が確認 されている. また， 3 種類のポリマーアロイの最大放熱 ピークはいずれもナイロン6マトリクスより上昇し，し かもエラストマー含有量が増えるにつれてより高温側に 移動するから結晶化温度が影響を受けることを示してい る. したがって, この結果もナイロン 6 とエラストマー 間に部分的な相溶性があることを示唆している。 また, エラストマー分子鎖におけるソフトセグメントの含有率
が多いほど高温側にシフトする. DSC の吸熱ピーク面 積から求めたナイロン 6 とそのアロイの相対結晶化度は Fig. 4 のようになり，エラストマー含有量の増加につれ て相対結晶化度は減少する。

\section{3 レオグラフによるガラス転移点 $\left(T_{g}\right)$}

Fig. 5 にアロイ中のエラストマー単独, ナイロン 6 お よびアロイの温度分散曲線を示した。 エラストマーの増 加につれてナイロン 6 のガラス転移点は低温側に移動し てやはりマトリックスとの間の部分的な相溶性のあるこ
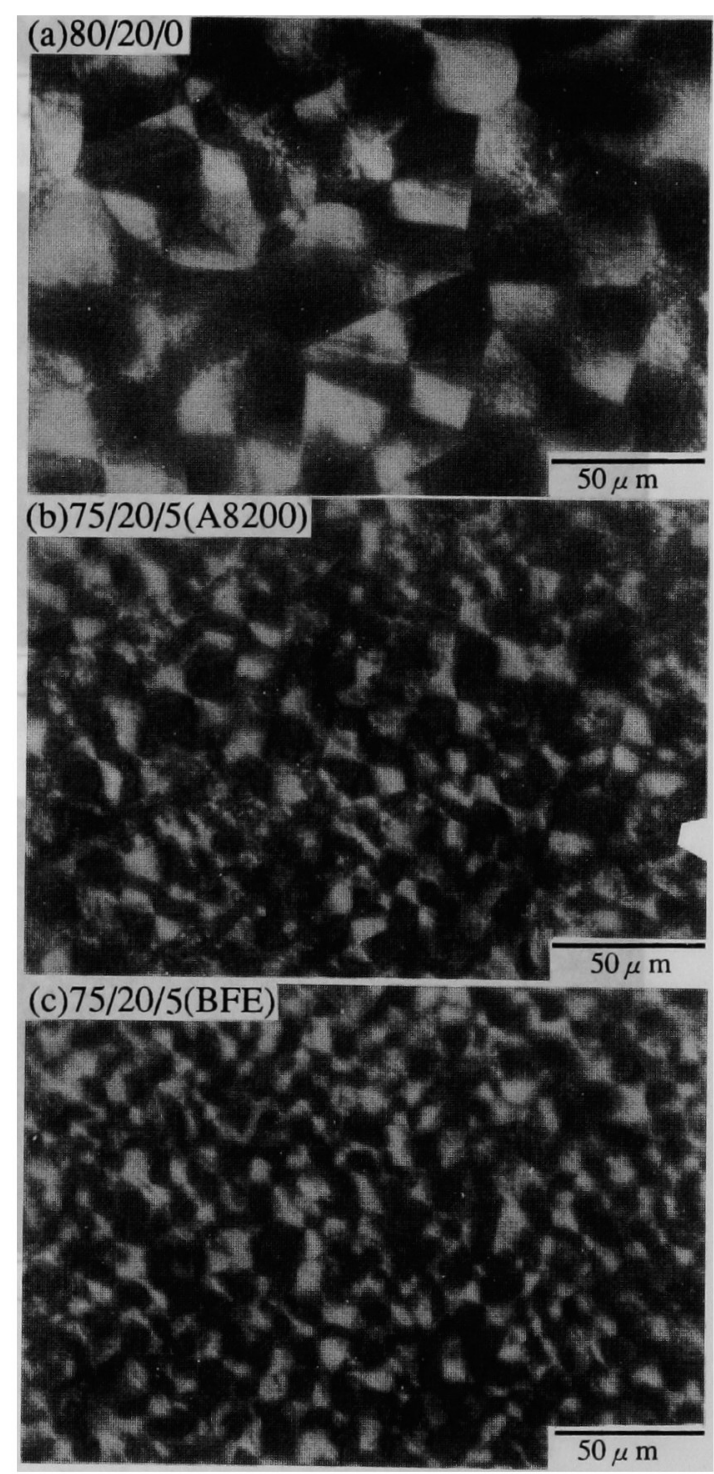

Fig. 8. POM photos of crystalline structure of Nylon 6/TPAE-10/Compatibilizer alloys. 
とを示している. この効果はエラストマーの種類によら ない。

\section{4 结晶蓝造}

まずポリマーアロイの各組成相の結晶構造を調べるた めに, 真空榦器でナイロン 6 とエラストマーをそれぞ れ $250^{\circ} \mathrm{C}, 3 \mathrm{~h}$ に保持した後 $150^{\circ} \mathrm{C}, 10 \mathrm{~h}$ 間等温結晶化を 行った. この偏光写真を Fig. 6 に示す. これらの写真か らナイロン6はもちろんであるが, エラストマー自身す 球晶棈造を形成することがわかる。このとき，ナイロン 6ではその球晶のサイズは不均一であり，いずれのエラ ストマーあほぼ均一サイスの球晶構造を持つ.

また等温結晶化したフイルムの偏光影微観察と光散乱 を行い,さらにポットプレスによるポリマーアロイ成形 板を薄い切片により偏光顥微鏡の钼察も行った. Fig. 7 は等温結晶化の結果を示したものである.この結果から あナイロン6の球晶はやはり大きさが不均一であり, TPAE-10 の添加量の増加につれて径は小さいが一定の 大きさの球晶が形成され, 光散乱パターンあ大きくなる ことがわかる. Fig. 8 は成形板の薄い切片の偏光顥微鏡 の写真であり，相溶化剂を添加したアロイでは均一の球 晶径が形成され，またこのときには相溶化剂 A8200よ り BFE 添加の方が球晶径はより小さくなる.すなわち 相溶化剤はナイロン 6 の球晶の径に影輩を与えることが わかる.

エラストマー量の増加は球晶の径を低下させ耐街撃性 の向上に有利となるが, 同時に弾性率の低下をもたらす ことも予想される. ナイロン 6 に対して反応性を持って いる相溶化刜の添加をすれば同一エラストマー添加でも

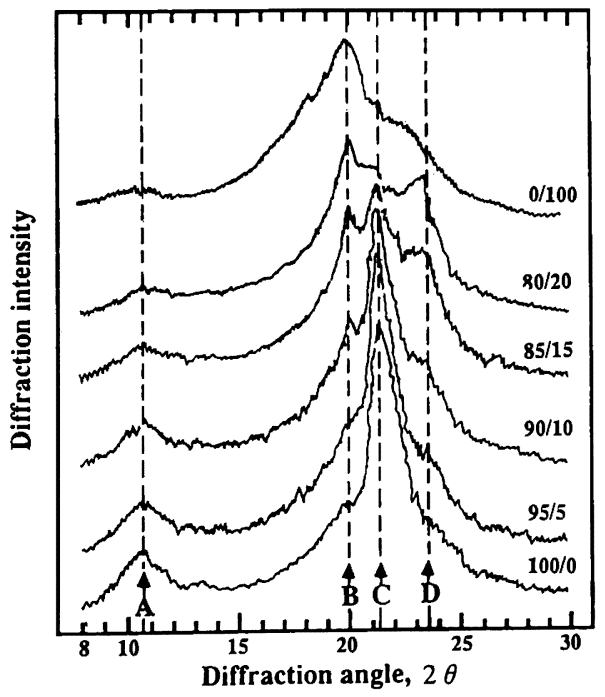

Fig. 9. X-Ray diffaction patterns of Nylon 6/ TPAE-8G alloy.
そのときの球晶径は小さくなる.さらに X 線広角回折 により結晶性を検討した. Fig. 9 と 10 はホットプレスに よる成形片の $\mathbf{X}$ 線回折強度曲線を示す.

Fig. 9 よりナイロン6の成形シートでは 2 種類の結晶 型が共存していることが分かる. $\mathbf{A}, \mathbf{C}$ ピークに対応する のが $\gamma$ 型結晶であり， B, D に対応するのが $\boldsymbol{\alpha}$ 型結晶で ある ${ }^{12)}$. エラストマー含有量の増加につれてナイロン 6 の $\gamma$ 型結晶の割合が低下し， $\boldsymbol{\alpha}$ 型結晶の割合が増加する ことが明らかである. また, Fig. 10 の TPAE-10C, 10, および 8G の添加によるポリマーアロイの X 線強度曲 線に示されるように, エラストマーの種類による結晶構 造の相違は, TPAE-10C の添加では $\gamma$ 型結晶割合が大き く,TPAE-10 と 8G はほとんど同じで $\alpha$ 型結晶の割合が 大きくなった.

なお，相溶化㶡がナイロン 6/TPAE-10=80/20 アロイ の結晶構造に影響をどのように与えるかを見るために，

手動射出成形機による試験片の $\mathbf{X}$ 線回折を検討した結 果を Fig. 11 に示す. ナイロン 6 および Nylon 6/TAPE$10=80 / 20$ アロイに比較すると，相溶化剂を添加したも のでは $\gamma$ 型結晶のピークが弱くなり， $\alpha$ 型結晶のピーク が強くなることが示される.

よく知られているように ${ }^{13)}, \boldsymbol{a}$ 型結晶は逆平行鎖の分 子構造であり, $r$ 型結晶は平行鎖の分子構造である. $\gamma$ 型 結晶はアミド基平面とメチレン基のジグザグ面が同一平 面になく, 分子鎖は $\alpha$ 型結晶よりわずかに䈹んでいる. また $\alpha$ 型結晶の分子鎖軸方向の結晶弾性率は約 $\gamma$ 型結 晶の 6 倍である. エラストマーを $20 \mathrm{wt} \%$ 添加したナイ ロン6アロイの結晶構造においても, マトリクスとあま り変わらない $\boldsymbol{\alpha}$ 型結晶と $\boldsymbol{\gamma}$ 型結晶が同時に存在するこ とが明らかになった.

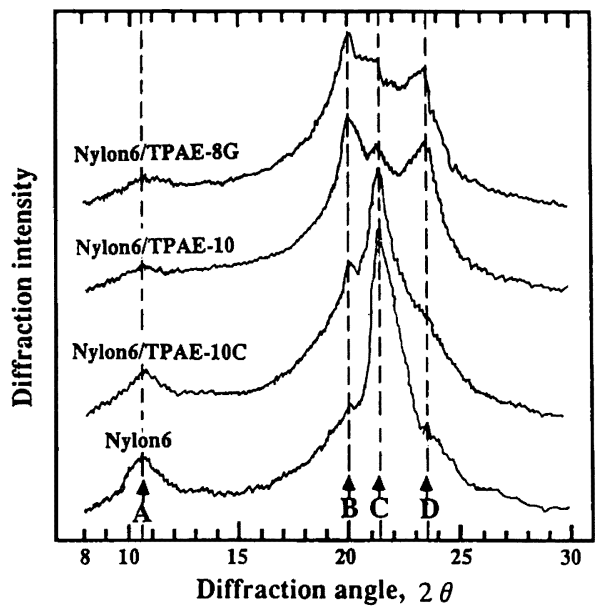

Fig. 10. X-Ray diffraction patterns of different Nylon $6 /$ Elastomer $=80 / 20$ alloys. 


\section{5 分散モルフォロジー}

ブチルアルコールで処理したサンプルを SEM と画像 解析により観察して結果 Fig. 12 と13 得た. SEM写 真から分散相エラストマーが抽出されて穴になっている ことが分かる.

Fig. 12 はエラストマーTPAEをブレント゚したポリ マーアロイの分散粒子直径とその標準偏差を示す。この 図からゴムの含有量の増加につれて分散相の粒子直径が 増大し分布も広くなり, 同じ添加量では 3 種類エラスト マーの分散特性はあまり違わないけれどあ TPAE-10C $\rightarrow$ TPAE-10 $\rightarrow$ TPAE-8G の順序にしたがって分散粒子 径がやや大きくなり, 分布範囲む広くなることが分か る.

また，SEM 写真 Fig. 13 から相溶化剤を用いたときに は，エラストマー粒子がよく分散されしかも分散粒子径 あかなり低下していることが分かる.

同じく, LSEM写真の Fig. 14 からエラストマー粒子

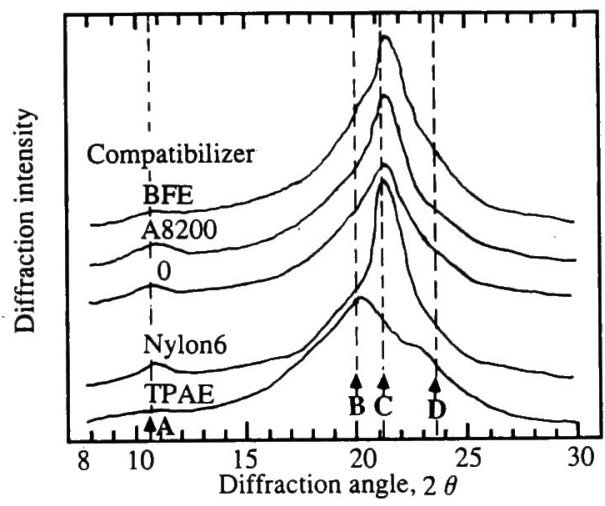

Fig. 11. X-Ray diffraction patterns.
中にはさらに微細化されたナイロン粒子が含まれている ことが分かる.したがって，一種のコアーシェル状でェラ ストマーが分散していることになる。

エラストマー分散相粒子径はアロイにおける球晶径の 1/100の大きさであるので，エラストマーはもちろん球 晶間の非晶相にも存在するが, 同時にナイロン 6 球晶内 に取り込まれてラメラ間隙に島状に取り残されることが 考えられる. 部分相溶性あるいはアミ/間の反応のため エラストマー分散粒子とナイロン 6 との界面は模式的に 示す Fig. 15 のようになっているものと思われる.

これらのエラストマーが強靱化において果たす力学的

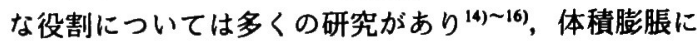
よるクレイズとボイド，応力集中，およびせん断降伏と キャビテーションなどの機構のあることが認められてい る. 特に変形中におけるエラストマーのキャビテーショ

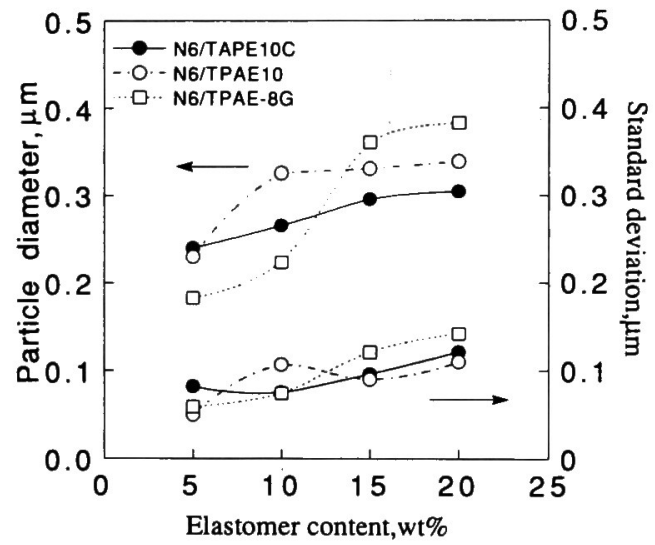

Fig. 12. Particle diameter of Nylon 6/Elastomer alloys obtained by Kneader-dual screw extruder.

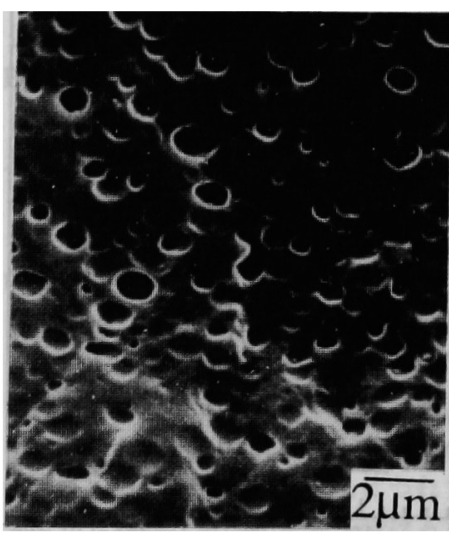

(a) $80 / 20 / 0$

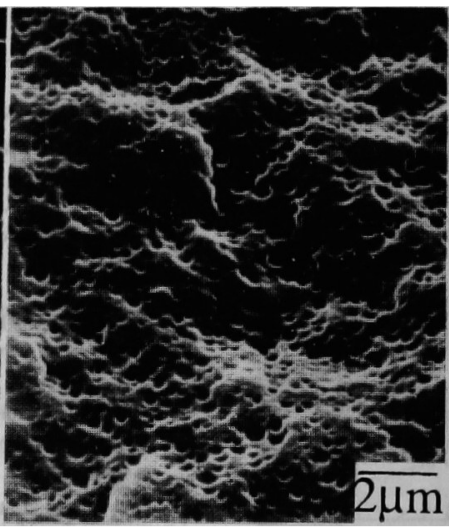

(b) $75 / 20 / 5(A 8200)$

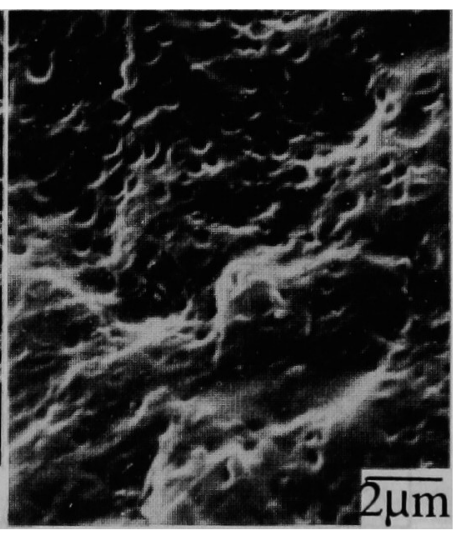

(c) $75 / 20 / 5$ (BFE)

Fig. 13. SEM photos of fracture surfaces of Nylon 6/TPAE-10/Compatibilizer alloys. 


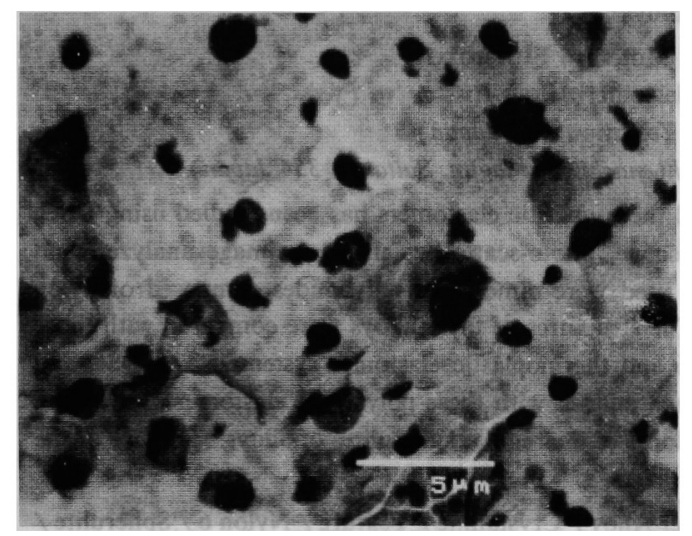

Fig. 14. A LSEM micrograph showing elastomer cavitation in Nylon 6/TPAE-10 $=80 / 20$ [wt\%] alloy.

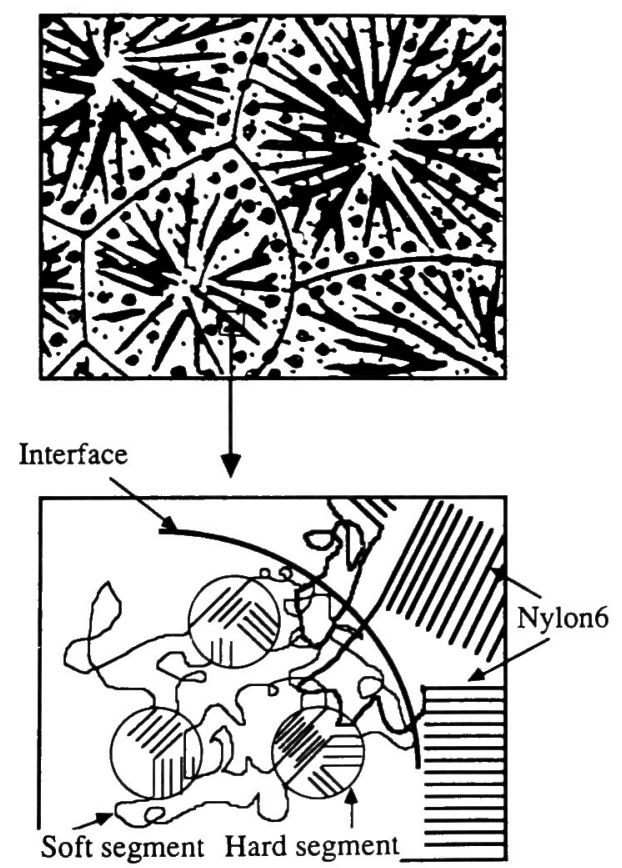

Fig. 15. A schematic illustration of elastomer dispersion within crystalline structure of Nylon 6.

ンは衝撃エネルギーの吸収をむたらすせん断降伏の発生 には大きなかかわりがあるとされる。 上述した構造を有 するナイロン 6 アロイの力学的性質については次報で詳
しく説明する.

$$
4 \text { ま と }
$$

1) ナイロン 6 とポリアミド熱可塑性エラストマーの ブレンドは部分的に相溶性を示す.

2) 球晶形態はエラストマーと相溶化剤の影響を受け る. すなわち単純なナイロン6では球晶の径は不均一で あり、エラストマーを添加したアロイでは均一な大きさ の球晶が生成し, 相溶化剂の添加で球晶は最む小さくな る. またエラストマー含有量の増加につれて球晶が小さ くなり結晶化度は低下する.

3) エラストマーTPAE-10C, TPAE-10, および TPAE-8Gを 20\% [wt] 添加したアロイではエラスト マー分散粒子平均直径はそれぞれ $0.38,0.40,0.49 \mu \mathrm{m}$ で あり, 相溶化剂はエラストマーの分散粒子平均直径を $0.3 \mu \mathrm{m}$ 以下に低下させる.

4) 同一ブレンド条件ではエラストマー分子鎖のソフ トセグメント含有量の増大につれて分散粒子径もやや大 きくなり球晶寸法は小さくなる.

\section{文献}

1) S. Wu, Polymer, 26, 1855 (1985).

2) R. J. M. Borggreve, R. J. Gaymans, J. Schuijer, and J. F. Ingen Housz, Polymer, 28, 1489 (1987).

3) 高分子学会, “ポリマーアロイ (基礎と応用)”、第 1 版第 5 刷, 化学同人(株), 東京 (1988), p. 195, p. 353.

4) Y. Takeda and D. R. Paul, J. Polym. Sci., B, Polym. Phys., 30, 1273 (1992).

5) R. Hollsti-Miettinen, J. Seppala, and O. T. Ikkala, Polym. Eng. Sci., 32, 868 (1992).

6) A. F. Yee and D. Li, Polymer, 34, 4471 (1993).

7) K. Dijkstra, J. ter Lask, and R. J. Gaymans, Polymer, 35, 315 (1994)

8) K. Dijkstra, H. H. Wevers, and R. J. Gaymans, Polymer, 35, 323 (1994).

9) A. J. Oshinski, H. Keskkula, and D. R. Paul, Polymer, 33, 268 (1992).

10) M. Lu, H. Keskkula, and D. R. Paul, Polymer, 34, 1874 (1993).

11) A. Crespy and C. Caze, Polym. Eng. Sci., 32, 273 (1992).

12) G. Curato, A. Fichera, F. Z. Grandi, R. Zannetti, and P. Cannal, Makromol. Chem., 175, 953 (1973).

13）福本修編, “ポリアミド樹脂ハンドブック”, 日刊工業新 聞社，東京 (1988), p. 76.

14) R. J. M. Borggreve, R. J. Gaymans, and H. M. Eichenwald, Polymer, 30, 78 (1989).

15)成沢郁夫, “高分子材料強度学”, オーム社, 東京 (1982), p. $107 \sim 155$.

16) A. F. Yee and R. A. Pearson, Mater. Sci., 21, 2462 (1986). 


\section{㕌・栗山・成澤・藤本}

\section{Structure and Morphology of Nylon 6/Polyamide-Elastomer Alloys*}

M.-S. ZhaN*1, Takashi KURIYAMA*1, Ikuo NARISAWA ${ }^{* 1}$, and Motohiro Fujimoto*2

*Studies on Structure and Properties of Nylon 6/Polyamide-Elastomer Alloys I.

*1 College of Engineering, Yamagata University (Jonan 4-3-16, Yonezawa, 992 Japan)

${ }^{* 2}$ Fuji Chemical Industry Co., Ltd. (Takemasawa 253-2, Miyoshi-machi, Irumagun, Saitama, 354 Japan)

The structure of polymer alloys composed of Nylon 6 and thermoplastic elastomers has been studied using DSC, Reograph, X-ray scattering analyzer, polarized optical microscope, photo-scattering analyzer, image analyzer, and scanning electron microscope. The thermoplastic elastomers used were dimer acid polyamides composed of nylon oligomers as hard segments and polyethers as soft segments. The structures of these alloys were compared with those obtained when the compatibilizer was added to these nylon 6 and thermoplastic elastomer systems. The DSC and mechanical loss curves showed that nylon 6 was partially compatibilized with these polyamide elastomers. Blending changed the crystalline texture from irregular spherulites of Nylon 6 to the regular spherulites of alloys. The size of the spherulites of the alloys was decreased by adding the compatibilizers.

KEY WORDS Thermoplastic Polyamide Elastomers / Polymer Alloy / Crystalline / Texture / Nylon 6 / Spherulite / (Received November 7, 1994: Accepted January 5, 1995)

[Kobunshi Ronbunshu, 52(5), 272-280 (1995)] 